\title{
Sea-ice extent in the Southern Ocean during the Last Glacial Maximum: another approach to the problem
}

\author{
Lloyd H. Burckle, Righard Mortlock \\ Lamont-Doherty Earth Observatory, Palisades, NY 10964, U.S.A.
}

\begin{abstract}
Determining past sea-ice distribution is an important goal of paleoceanographers. Here, we present a possible approach to determining past sea-ice distribution in the Southern Ocean during the Last Glacial Maximum (LGM). Diatoms are the principal opal-forming organisms south of the Antarctic Polar Front; their productivity is partly mediated by the presence/absence of sea ice. We reasoned that there should be good coherence between percentage biogenic opal in surface sediments and percentage annual sea-ice cover. This hypothesis was tested by comparing percentage biogenic opal in surface sediments against modern-day sea-ice cover in surface waters directly above each core site. The chronology for each core was determined by various means (biostratigraphy, ${ }^{14} \mathrm{C}$ age dating, and carbonate and opal stratigraphy). With the resulting curve we estimate that yearly concentration of sea ice can be determined to within $30 \%$. Using these data, we estimated percentage sea-ice cover during the LGM for a number of sediment sites $\left(50-66^{\circ} \mathrm{S}\right)$ from the Southern Ocean. Core sites now beneath $100 \%$ open water witnessed some $25-60 \%$ sea ice during the LGM, while core sites presently beneath sea ice during half of the year witnessed more than $75 \%$ sea-ice cover during the LGM.
\end{abstract}

\section{INTRODUGTION}

Determining past sea-ice distribution in the Southern Ocean has been an elusive goal of paleoceanographers and climate modellers. Previous efforts by CLIMAP (1981) were only partially successful; their lithologically based Last Glacial Maximum (LGM) summer sea-ice boundary (Cooke, 1978; CLIMAP, 1981; Cooke and Hays, 1982) was challenged by Burckle and others (1982) who demonstrated that it was a spring sea-ice boundary (Burckle and Cirilli, 1987). Further, if one examines maps of winter and summer sea-ice limits of Cooke (1978) it is clear that the data from LGM sediments were in sufficient detail only for the Atlantic and southwest Indian oceans. More recent work suggests that the spring sea-ice limit in the Pacific sector during the LGM may have been very modest: on the order of a few degrees north of its present position (Burckle and Cirilli, 1987). Other studies have used geochemical approaches, such as stable isotopes, but such efforts have largely been restricted to the sub-Antarctic and Polar Front region where the North Atlantic Deep Water is implicated in sea-ice buildup and drawback (Charles and Fairbanks, 1992). Such studies say very little about the percentage of sea-ice cover during the year, and consequently fall short of the needs of paleoceanographers and climate and oceanographic modellers.

Here, we present one possible approach to determining past (i.e. LGM) sea-ice distribution in the Southern Ocean. This is our reasoning. For regions south of the present Antarctic Polar Front, most diatom productivity should be mediated by the presence/absence of sea ice. Secondly, since diatoms are the principal opal-forming organisms, there should be reasonable coherence between percentage biogenic opal in surface sediments and percentage annual seaice cover. However, two questions are first addressed. Is di- atom productivity related to the presence/absence (i.e. the extent) of sea ice? Is percentage biogenic opal in surface sediments related to sea-surface productivity?

Is diatom productivity related to the presence/absence of sea ice?

Two datasets are considered: surface-water diatom productivity (Hart, 1942) and modern-day sea-ice distribution from satellite imagery (National Snow and Ice Data Center (NSIDC), University of Colorado). Hart (1942) divided the Southern Ocean zonally into three regions: the northern region, north of the present-day Polar Front; an intermediate region which straddles the Polar Front; and a southern region which extends from the intermediate region to the Antarctic continent. The northern region is ignored here since sea ice does not extend this far. Diatom productivity (expressed as plant pigment $\mathrm{m}^{-3}$ ) for each month for each region was taken from Hart (1942). These data, although generated more than 50 years ago, are used because they are multi-year, circum-Antarctic and were collected as far into the winter season as weather and sea-ice conditions permitted. Using satellite imagery, the average percentage seaice cover for each month of the year for the southern and intermediate regions was also determined (Fig. la and b). Productivity in the southern region (Fig. la) is clearly related to sea-ice extent. When sea ice begins to melt back in the spring, diatom productivity increases dramatically. In contrast, when sea ice returns in the early fall, productivity declines. A perfect correlation does not emerge for the intermediate region (Fig. 1b). Although there is good agreement between the decline of sea ice and the rise of productivity in the spring, fall production drops before sea ice 

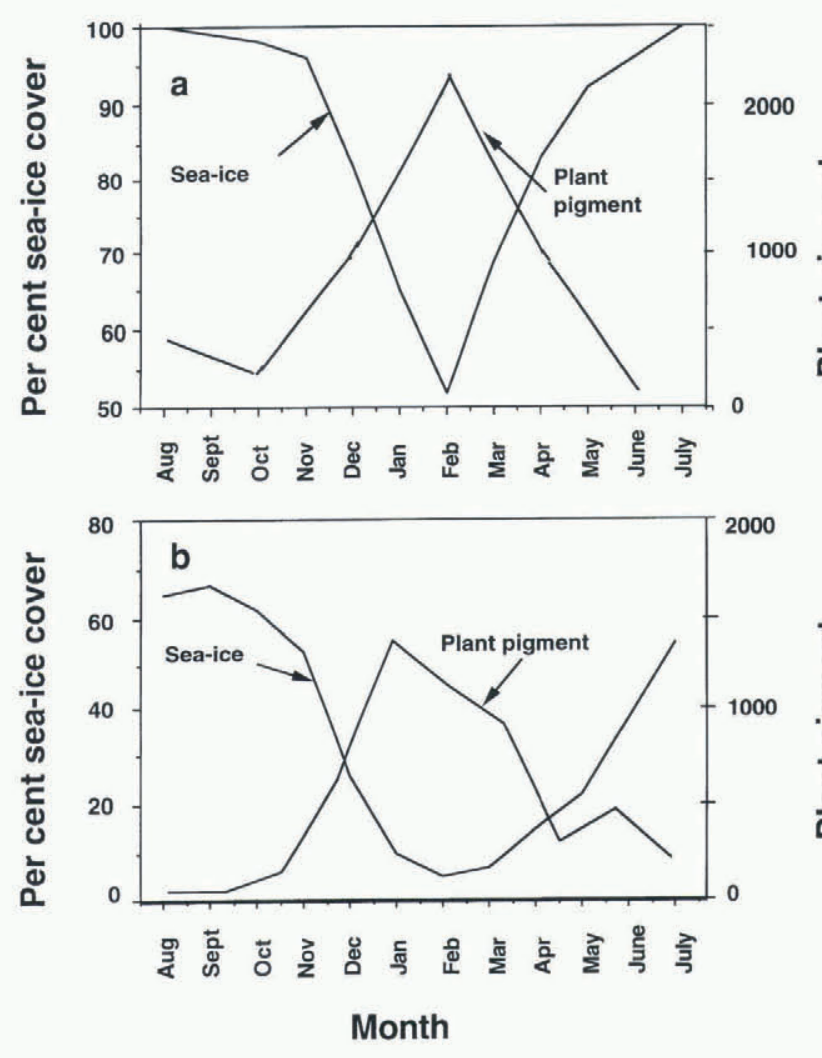

Fig. 1. Sea-ice concentration and plant pigment (measured as plant pigment $\mathrm{m}^{-3}$ ) for (a) southern region of Hart (1942) and (b) intermediate region of Hart (1942). Percentage seaice cover is taken from $\mathcal{N S I D C}$.

begins to build up again. Nevertheless, the bulk of production occurs during the minimum sea-ice period.

\section{Does percentage biogenic opal in surface sediments reflect sea-surface productivity?}

One of us (L.H.B.) has made a census of diatom presence/ absence in the surface sediment of more than 3000 cores from the world's oceans. This distribution accurately reflects surface water productivity. Diatoms occur beneath equatorial upwelling regions as well as beneath western and eastern boundary currents but are not found in surface sediments beneath the central water masses. In the Southern Ocean, diatoms occur in significant numbers between the sub-Antarctic Front and the Antarctic Slope Front (Burckle and others, 1987), both in the water column and in underlying surface sediments. To the south of the Antarctic Slope Front, except for polynyas, diatom productivity is suppressed by the presence of sea ice into the growing season, while, to the north of the sub-Antarctic Front (i.e. in the southern part of the central water mass), it is suppressed by temperatures in excess of $8^{\circ} \mathrm{C}$ and low nutrient supply (Neori and Holm-Hanson, 1982; Burckle and others, 1987; Sullivan and others, 1993).

That sea ice suppresses diatom productivity is not surprising. Diatoms are photosynthetic and require access to sunlight as well as to nutrients in the water column. They do occupy niches in sea ice, but many of these forms tend to be weakly silicified and are dissolved when released to the water column (see, e.g., Burckle, 1987). Further, a number of studies (Lozano and Hays, 1976; CLIMAP, 1981; Cooke and Hays, 1982) indicate that sea ice was much more extensive around Antarctica during the LGM and that it per-

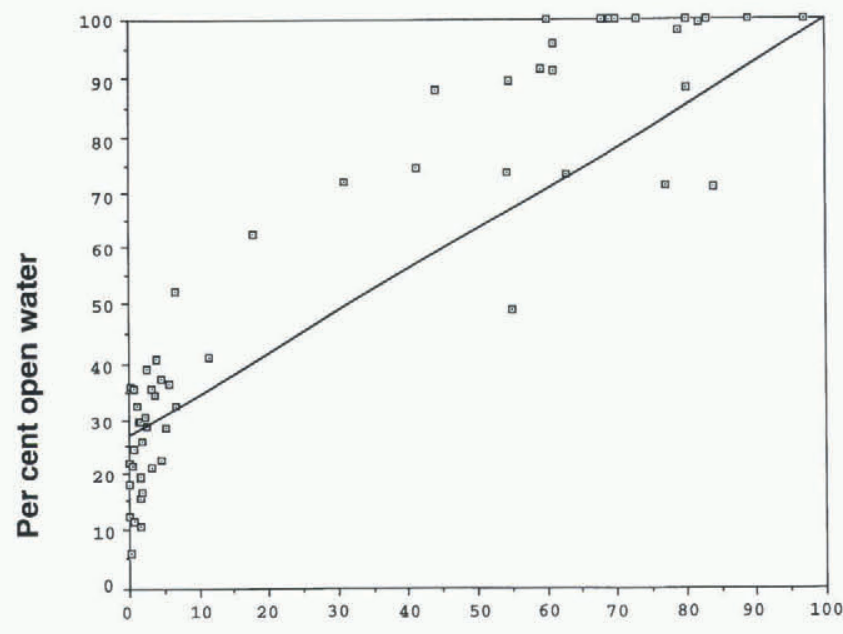

Per cent opal

Fig. 2. Percentage open water vs percentage opal in surface sediments. Estimates of percentage sea-ice cover during the LGM were taken from this diagram.

sisted into the spring growing season (Burckle and others, 1982). In such circumstances, one would expect lower percentage opal in sediments representing the LGM. This was found to be the case in the South Atlantic (Mortlock and others, 1991). These authors reported significantly lower percentage opal at the LGM in sediment that, according to the CLIMAP (1981) reconstruction, was covered by sea ice for at least part of the year. Based upon these studies, our hypothesis is that sea ice plays a role in mediating surface water productivity for those regions which are covered by sea ice during part of each year, and that percentage biogenic opal in surface sediments reflects changes in sea-ice mediated productivity. Our further hypothesis is that, within limits, percentage opal in LGM sediments can be used to estimate sea-ice concentration during this climatic extreme.

\section{RESULTS}

We tested this hypothesis by comparing percentage biogenic opal (Mortlock and Froelich, 1989) in surface sediments from 62 cores against modern-day sea-ice cover in surface waters directly above each core site. Most cores used in this test were beneath sea ice during part of each year; a few cores not covered by sea ice were also included. Chronology for each core was determined by various means, including biostratigraphy, ${ }^{14} \mathrm{C}$ age dating, and carbonate and opal stratigraphy. We added to our own analyses a number of opal measurements drawn from the published literature (Schlütter, 1990). In each case, it was determined that the core top represented the Holocene, although there is no certainty that it was the latest Holocene. Percentage sea ice (during the year) at each core site was accessed from the NSIDC.

The results show good coherence between percentage opal and percentage open water (Fig. 2). Using the resulting curve, we estimate that yearly concentration of open water can be determined to within $20-30 \%$. Table 1 gives our estimate of percentage open water during the LGM for six sediment cores $\left(50-66^{\circ} \mathrm{S}\right)$ from the Pacific and Atlantic sectors. Core sites that are now beneath $100 \%$ open water witnessed some $25-60 \%$ sea ice during the LGM. Especially instruc- 
tive are the cores Robert Conrad 11-76, -77 and -78 which were taken on a southwest-northeast track in the Atlantic sector. Based upon present-day sea-ice distribution, one would expect LGM sea ice to have a higher yearly concentration in RCll-76, and a lower concentration in RCll-78. Robert Conrad 11-76 had 40-60\% sea ice during the LGM. To the north and east of this core, Robert Conrad 11-77 $\left(53^{\circ} \mathrm{S}\right)$ had $35-55 \%$ sea ice during the LGM, while RCll$78\left(50^{\circ} \mathrm{S}\right)$ had $25-45 \%$ sea ice during this time. A core taken further to the east and $2^{\circ}$ of latitude to the south of RC11-78 (Robert Conrad 13-271; Table 1) had similar sea-ice concentration during the LGM $(30-50 \%)$.

Table 1. Modern-day sea-ice distribution at selected core sites, and estimate of percentage sea-ice cover at these sites during the LGM

\begin{tabular}{|c|c|c|c|c|c|}
\hline Core site & Lat./long. & $\begin{array}{c}\% \text { Opal } \\
(\mathrm{H})\end{array}$ & $\begin{array}{c}\% \text { Sea ice } \\
\text { (H) }\end{array}$ & $\begin{array}{l}\% \text { Opal } \\
\text { (LGM) }\end{array}$ & $\begin{array}{l}\% \text { Sea ice } \\
\text { (LGM) }\end{array}$ \\
\hline Eltanin $17-17$ & $66.59^{\circ} \mathrm{S} ; 120.05^{\circ} \mathrm{E}$ & 54 & 26 & 7 & $60-80$ \\
\hline Eltanin $20-10$ & $60.20^{\circ} \mathrm{S} ; 127.05^{\circ} \mathrm{W}$ & 81 & 0.5 & 67 & $10-30$ \\
\hline $\begin{array}{l}\text { Islas Orcadas } \\
\quad 1277-10\end{array}$ & $52.01^{\circ} \mathrm{S} ; 20.47^{\circ} \mathrm{E}$ & 82 & 0 & 47 & $30-50$ \\
\hline $\begin{array}{l}\text { Islas Orcadas } \\
1578-4\end{array}$ & $59.23^{\circ} \mathrm{S} ; 19.727^{\circ} \mathrm{W}$ & 62 & 27 & 13 & $50-70$ \\
\hline $\begin{array}{l}\text { Robert Conrad } \\
\quad 11-76\end{array}$ & $54.383^{\circ} \mathrm{S} ; 22.133^{\circ} \mathrm{W}$ & 70 & 0 & 30 & $40-60$ \\
\hline $\begin{array}{l}\text { Robert Conrad } \\
11-77\end{array}$ & $53.05^{\circ} \mathrm{S} ; 16.45^{\circ} \mathrm{W}$ & 68 & 0 & 40 & $35-55$ \\
\hline $\begin{array}{l}\text { Robert Conrad } \\
\quad 11-78\end{array}$ & $50.867^{\circ} \mathrm{S} ; 09.867^{\circ} \mathrm{W}$ & 80 & 0 & 55 & $25-45$ \\
\hline $\begin{array}{l}\text { Robert Conrad } \\
13-271\end{array}$ & $51.59^{\circ} \mathrm{S} ; 04.31^{\circ} \mathrm{E}$ & 64 & 0 & 50 & $30-50$ \\
\hline
\end{tabular}

$\mathrm{H}=$ Holocene.

\section{DISGUSSION}

Although we view this approach as a viable way to determine past sea-ice distribution, we also acknowledge some shortcomings. Clearly, our sample size is not sufficient and the data base needs to be enlarged. In enlarging this data base, we need to recognize the spatial differences in productivity in the Southern Ocean, particularly between the Atlantic and Pacific sectors. Separate diagrams, similar to Figure 2, need to be constructed for each sector. We also need to consider sediment dilution from non-biogenic sources (iceberg and sea-ice rafting, eolian input, etc.). Further, it should be noted that diatom productivity (and percentage opal in surface sediments) falls off toward the sub-Antarctic Front which is well north of the maximum limits of sea ice. This drop in productivity is due to temperature constraints and nutrient limitation (Neori and Holm-
Hanson, 1982; Burckle and others, 1987) and is not related to sea-ice cover. Finally, we need to compare these results with those obtained using other approaches. If a consensus or near-consensus emerges, then we have a new set of boundary conditions for paleoceanographers and climate modellers.

\section{ACKNOWLEDGEMENTS}

We thankJ. Kennett and our colleagues at Lamont-Doherty for review and discussion. Support came from the U.S. Antarctic Research Program of the National Science Foundation. This is Lamont-Doherty Earth Observatory contribution No. 5717.

\section{REFERENCES}

Burckle, L. H. 1987. Diatom distribution in the Weddell Sea during late winter, 1987. Micropaleontology, 33, 177-184.

Burckle, L. H. and J. Cirilli. 1987. Origin of diatom ooze belt in the Southern Ocean: implications for late Quaternary paleoceanography. Micropaleontology, 33, $82-86$.

Burckle, L. H., D. Robinson and D.W. Cooke. 1982. Reappraisal of sea ice distribution in Atlantic and Pacific sectors of the Southern Ocean at 18,000 yrs BP. Nature, 299 (5882), 435-437.

Burckle, L. H., S. S. Jacobs and R. M. McLaughlin. 1987. Late spring diatom distribution between New Zealand and the Ross Sea: correlation with hydrography and bottom sediments. Micropaleontology, 33, 77-81.

Charles, C. D. and R. G. Fairbanks. 1992. Evidence from Southern Ocean sediments for the effect of North Atlantic deep-water flux on climate. Nature, 355(6359), 416-419.

CLIMAP Project Members. 1981. Seasonal reconstructions of the Earth's surface at the last glacial maximum. Boulder, CO, Geological Society of America. (Map Chart MC-36.)

Cooke, D.W. 1978. Variations in the seasonal extent of sea ice cover in the Antarctic during the last 140,000 years. (Ph.D. thesis, Columbia University.)

Cooke, D.W. and J. D. Hays. 1982. Estimates of Antarctic Ocean seasonal sea-ice cover during glacial intervals. In Craddock, C., ed. Antartic geoscience. Madison, WI, University of Wisconsin Press, 1017-1025.

Hart, T.J. 1942. Phytoplankton periodicity in Antarctic surface waters. Discovery Rep., 21, 261-356.

Lozano, J. A. and J. D. Hays. 1976. Relationship of radiolarian assemblages to sediment types and physical oceanography in the Atlantic and western Indian Ocean sectors of the Antarctic Ocean. In Cline, R. M. and J. D. Hays, eds. Investigation of late Quaternary paleooceanography and paleoclimatology. Boulder, CO, Geological Society of America, 303-336. (GSA Memoir 145.)

Mortlock, R. A. and P. N. Froelich. 1989. A simple method for the rapid determination of biogenic opal in pelagic marine sediments. Deep-Sea Res., Ser. $I, 36(9), 1415-1426$.

Mortlock, R. A. and 6 others. 1991. Evidence for lower productivity in the Antarctic ocean during the last glaciation. Nature, 351 (6323), 220-223.

Neori, A. and O. Holm-Hansen. 1982. Effect of temperature on rate of photosynthesis in Antarctic phytoplankton. Polar Biol., 1(1), 33-38.

Schlütter, M. 1990. Early diagenesis of organic carbon and opal in sediments of the southern and eastern Weddell Sea: geochemical analysis and modelling. Ber. Polarforsch. 73.

Sullivan, C. W., K. R. Arrigo, C. R. McClain, J. C. Comiso and J. Firestone. 1993. Distributions of phytoplankton blooms in the Southern Ocean. Science, 262(5141), 1832-1837. 